\title{
Egy kiberfilmográfia első vázlata
}

A szerző a tudományos fantasztikus, a cyber és a fantasy filmek határvonalán mozogva, egy régi-új műfaj, a cyber filmek listáját állítja össze 1982-től kezdve. A cikk célja sokkal inkább egy konstruktív vita és közösségi gyűjtés elindítása, mintsem a teljességre törekvés - ennek ellenére már az induló lista is meghaladja a 100 tételt...

Kulcsszavak: film, mozi, sci-fi, fantasy, cyber

Így hivatkozzon erre a cikkre:

Décsy Eszter. „Egy kiberfilmográfia első vázlata.”

Információs Társadalom IX, 1. szám (2009): 81-85.

= https://dx.doi.org/10.22503/inftars.IX.2009.1.9

A folyóiratban közölt múvek

a Creative Commons Nevezd meg! - Ne add el! - Így add tovább! 4.0

0

Nemzetközi Licenc feltételeinek megfelelöen használhatók. 
Décsy Eszter

\section{Egy kiberfilmográfia elsốvázlata}

A tudományos-fantasztikus irodalom és a nyomában némi fáziskéséssel fejlódésnek indult tudományos-fantasztikus filmmúvészet nagyon sokáig afféle „gyújtókategóriaként" múködött, minden, a jövố technológiai és társadalmi kihívásaihoz kötődő témát (az idô- és úrutazásokkal, idegen lényekkel, más életformákkal, robotokkal, természeti katasztrófákkal, Földünk feltáruló „titkaival” kapcsolatos történeteket egyaránt) magába olvasztva.

Azután kb. húsz-huszonöt éve egyszercsak radikálisan elkezdett kettéválni a „tudományos-fantasztikus” és a fantasyirodalom és -film, visszamenóleg is „kettéosztva” az addig homogén hagyományt. Az „elképzelt világok” modern narratívájának ősforrását Tolkienben megtalálva, önálló életre kelt, és robbanásszerú fejlődésnek indult a tematikáját térben és idóben is kiterjesztố fantasy, amely a közösségi kaland- és szerepjátékokkal új „platformot” is teremtett (jóval megelőzve a számítógépek valóban tömeges elterjedését).

Ezzel nagyjából egy idóben azonban a tudományos-fantasztikus oldalon is elképesztố tematikai bóvülés tanúi lehettünk azzal párhuzamosan, ahogyan a mesterségesintelligencia-kutatások, az agykutatás, a genetikai beavatkozások és a számítógépes szimulációk világa rohamos fejlődésnek indult. Az új könyvek és filmek nagy száma miatt jó néhány évnek kellett eltelnie, hogy visszamenóleg is felismerhetốvé váljon: a 60-as évek elején valami új született meg, amit az irodalom- és filmtörténet, ahogy szokta, emblematikus alkotásokhoz mint szakaszhatárhoz rendel.

Nagyjából egy idóben történt szinte minden. Philip K. Dick Álmodnak-e aะandroidok elektronikus bárányokkal? címú, 1968-as regényét, amely a „,biológiai ember” és a „mesterséges ember" közötti határokra kérdezett rá, Ridley Scott vitte vászonra 1982-ben, Szárnyas fejvadász címmel. Ugyanebben az évben készült el Steven Lisberger TRON címú filmje, amelyben egy videojáték „,virtuális valóságával” keverednek a valóságos identitások, s végül 1984-ben jelent meg William Gibson alapmúve, a Neuromancer, amely a hálózati világgal, a kibertérrel sajátos, „feloldódásszerû” kapcsolatba kerülő hôsökön keresztuil épített fel egy erôsen disztópikus jövővíziót.

Gibson regényével (pontosabban már egy évvel korábban, Bruce Bethke 1983-ban megjelent Cyberpunk címú novellájával) ölt testet és válik nagykorúvá és egyben elfogadottá - tíz-egynéhány évvel az internet forradalma elốtt - a hálózattal szimbiózisba kerüló ember, a számítógépek által generált valóságot, az elme és a test újszerú összekapcsolódásának lehetôségeit firtató „cyberirodalom” és „kiberfilm”. Az úttörô „cyberpunk” (amely elsôsorban sajátos világképe - „high tech, low life” - révén különül el a hasonló tematikájú múvektól) mára már a sokkal átfogóbb „kibermúvészet” egyik irányzatává „,szelídült””.

Mind a kiberirodalom, mind a kiberfilm az információs korszak megkülönböztetetten izgalmas múvészeti ága. Mindkettố alapvetố filozófiai, antropológiai, társadalomelméleti kérdéseket vet fel és boncolgat, s ezeket a kérdéseket a múfaj népszerúsége 
folytán olvasók és nézốk százmilliói számára tudatosítja, tematizálva a közgondolkodást, és folyamatosan szállítva parázs viták és komoly párbeszédek kiindulási anyagát.

Noha egyes külföldi filmfesztiválokon már jó ideje önálló kategória a „kiberfilm”, a múfaj hatóköre, pontos értelmezése, típusai, esztétikája és világképe még formálódóban van. Az erról folyó viták egyelốre nem látványosak és nem szenvedélyesek, a szakirodalom esetleges, szórványos és szegényes, de a témakör népszerúsége és keveredése a tömegkultúra rokon területeivel (idesorolhatjuk az MMORPG játékokat, a hétköznapivá lett hálózati írástudást és az „augmentált valóságokat”) a közeljövóben várhatóan felértékeli a tisztázó diskurzusokat.

E majdani párbeszédet „könyvtárosi” oldalról megtámogatva, szüikségesnek láttam tehát egy olyan filmográfia összeállítását, amely a tudományos-fantasztikus filmtermésen ${ }^{1}$ belül elkülöníti az ún. kiberfilmeket. ${ }^{2}$ Az elsóként az Információs Társadalom címú folyóiratban közzétett filmográfia pusztán „,béta-változatnak” tekinthetô, számos hiányossággal küzd. Jelenleg alig több mint száz tételt tartalmaz, s ezek közül sokat nem is forgalmaztak Magyarországon, így ezeknek nincs magyar címük. A lista legtöbb tétele angol nyelvterületról származik, fóleg az Egyesült Államokból, s noha jócskán képviseltetik magukat a japán filmek is, kevésbé ismert voltuk miatt a számuk feltehetốen jóval nagyobb.

A lista bizonyosan bóvíthető, ${ }^{3}$ de talán már jelenlegi állapotában is alkalmas arra, hogy vitát provokáljon a legfontosabb, elemzést igénylő kérdésekben. Milyen megfontolások alapján sorolunk egy filmet a „kiberfilm” kategóriájába? Milyen tematikai elemeknek kell feltétlenül jelen lenniük benne, és az előfordulások függvényében ezek milyen „alkategóriákat” definiálnak? Milyen motívumfolyamokat tudunk elkülöníteni, maga a filmnyelv milyen narratívákat jelenít meg, milyen dilemmákat vet fel, és milyen megoldásokat sugall? Mennyire egységes ez a hagyomány? Mi a dinamikája, milyen irányba halad? Hogyan viszonyuljunk ahhoz, hogy a kibertematika túlnyomórészt disztopikus jövôképhez kapcsolódik? És végül, de nem utolsósorban: Hol vannak a magyar alkotások? Miért nem érzékeny a magyar filmmúvészet erre a témára?

\begin{tabular}{|c|c|c|c|}
\hline Évszám & Eredeti cím & Magyar cím & Rendező \\
\hline 1982 & Android & & Aaron Lipstadt \\
\hline 1982 & Blade Runner & Szárnyas fejvadász & Ridley Scott \\
\hline 1982 & TRON & $\begin{array}{l}\text { Tron, avagy a számítógép } \\
\text { lázadása }\end{array}$ & Steven Lisberger \\
\hline 1984 & The Terminator & Terminátor - A halálosztó & James Cameron \\
\hline 1985 & Brazil & Brazil & Terry Gilliam \\
\hline 1987 & Not Quite Human & & $\begin{array}{l}\text { Steven Hilliard } \\
\text { Stern }\end{array}$ \\
\hline 1987 & Robo Cop & Robotzsaru & Paul Verhoeven \\
\hline 1988 & Droid & & Philip O'Toole \\
\hline
\end{tabular}




\begin{tabular}{|c|c|c|c|}
\hline Évszám & Eredeti cím & Magyar cím & Rendezó \\
\hline 1988 & Snatcher & & Hideo Kojima \\
\hline 1989 & Black Rain & Fekete eső & Ridley Scott \\
\hline 1989 & Cyborg & Cyborg - A robotnô & Albert Pyun \\
\hline 1989 & Not Quite Human 2 & & Eric Luke \\
\hline 1989 & Quarantine & & Charles Wilkinson \\
\hline 1989 & Quarantene & & Nico Hofmann \\
\hline 1990 & Circuit's Edge & & \\
\hline 1990 & Cyberpunk & & Marianne Trench \\
\hline 1990 & Hardware & & Richard Stanley \\
\hline 1990 & Robo Cop 2 & Robotzsaru 2. & Irvin Kershner \\
\hline 1990 & Super Deform Snatcher & & Hideo Kojima \\
\hline 1990 & Total Recall & Az emlékmás & Paul Verhoeven \\
\hline 1991 & 964 Pinocchio & & Shozin Fukui \\
\hline 1991 & $\begin{array}{l}\text { Bis ans Ende der Welt (Until the } \\
\text { End of the World) }\end{array}$ & A világ végéig & Wim Wenders \\
\hline 1991 & Terminator 2: Judgment Day & Terminátor 2. - Az ítélet napja & James Cameron \\
\hline 1992 & $\begin{array}{l}\text { Confessions d'un Barjo } \\
\text { (Confessions of a Crap Artist) }\end{array}$ & Egy naiv múvész vallomásai & Jérôme Boivin \\
\hline 1992 & Frecjack & Szabad préda & Geoff Murphy \\
\hline 1992 & Snatcher CD-Romantic & & Hideo Kojima \\
\hline 1992 & Sneakers & Komputerkémek & $\begin{array}{l}\text { Phil Alden Robin- } \\
\text { son }\end{array}$ \\
\hline 1992 & The Lawnmower Man & A fúnyíró ember & Brett C. Leonard \\
\hline 1993 & American Cyborg: Steel Warrior & Amerikai ciborg & Boaz Davidson \\
\hline 1993 & $\begin{array}{l}\text { Brave New Worlds: The Sciece } \\
\text { Fiction Phenomenon }\end{array}$ & & Paul Oremland \\
\hline 1993 & Cyborg 2. & Cyborg 2. - Üvegárnyék & Michael Schroeder \\
\hline 1993 & Demolition Man & & Marco Brambilla \\
\hline 1993 & Mandroid & & Jack Ersgard \\
\hline 1993 & Robo Cop 3. & Robotzsaru 3. & Fred Dekker \\
\hline 1994 & Burn: Cycle & & Eitan Arrusi \\
\hline 1994 & Cyber Tracker & A menekülés & Richard Pepin \\
\hline 1994 & Cyberteens in Love & & Brett Dowler \\
\hline 1994 & Cyborg Cop & Cyborg zsaru & Sam Firstenberg \\
\hline 1994 & Policeratus & & Hideo Kojima \\
\hline 1995 & Cyber Tracker 2 & A menekülés 2. & Richard Pepin \\
\hline 1995 & Cyberjack & Cyberjack - Gyilkos a jövóból & Robert Lee \\
\hline 1995 & Cyberstalker & & $\begin{array}{l}\text { Christopher } \\
\text { Romero }\end{array}$ \\
\hline 1995 & Cyborg 3: The Recycler & A Teremtó & Michael Schroeder \\
\hline 1995 & Glacier & & Cam Eason \\
\hline 1995 & Hackers & Adatrablók & Iain Softlcy \\
\hline
\end{tabular}




\begin{tabular}{|c|c|c|c|}
\hline Évszám & Eredeti cím & Magyar cím & Rendezô \\
\hline 1995 & Johnny Mnemonic & $\begin{array}{l}\text { Johnny Mnemonic-A jövó } \\
\text { szökevénye }\end{array}$ & Robert Longo \\
\hline 1995 & Judge Dredd & Dredd bíró & Danny Cannon \\
\hline 1995 & $\begin{array}{l}\text { Kokaku kidotai (Ghost in the } \\
\text { Shell) }\end{array}$ & Páncélba zárt szellem & Mamoru Oshii \\
\hline 1995 & Screamers & Az elhagyott bolygó & Christian Duguay \\
\hline 1995 & Strange Days & A halál napja & Kathryn Bigelow \\
\hline 1995 & Terminal Justice & Klóncsapda & Rick King \\
\hline 1995 & The Android Affair & Szerelmes gépember & Richard Kletter \\
\hline 1995 & Twelve Monkies & 12 majom & Terry Gilliam \\
\hline 1995 & Virtuosity & Sid 6.7 - A tökéletes gyilkos & Brett C. Leonard \\
\hline 1996 & Absolute Agression & & $\begin{array}{l}\text { J. Christian } \\
\text { Ingvordsen }\end{array}$ \\
\hline 1996 & Subliminal Seduction & & Andrew Stevens \\
\hline 1996 & Virtual Combat & Élő robotok & Andrew Stevens \\
\hline 1997 & Abre los ojos (Open Your Eyes) & Nyisd ki a szemed! & $\begin{array}{l}\text { Alejandro } \\
\text { Amenábar }\end{array}$ \\
\hline 1997 & Blade Runner & & Joseph D. Kucan \\
\hline 1997 & Cube & A kocka & Vincenzo Natali \\
\hline 1997 & Nirvana & Nirvána & Gabricle Salvatores \\
\hline 1997 & The Fifth Element & Az ötödik elem & Luc Besson \\
\hline 1998 & Dark City & Sötét város & Alex Proyas \\
\hline 1999 & Bicentennial Man & A kétszáz éves ember & Chris Columbus \\
\hline 1999 & eXistenZ & eXistenZ - Az élet játék & David Cronenberg \\
\hline 1999 & The Matrix & Mátrix & $\begin{array}{l}\text { Andy Wachowski, } \\
\text { Larry Wachowski }\end{array}$ \\
\hline 1999 & The Thirteenth Floor & 13. emelet & Joseph Rusnak \\
\hline 2000 & Robo Cop 4. & Robotzsaru 4. - Sötét igazság & Julian Grant \\
\hline 2000 & The 6th day & A 6. napon & Roger Spottiswoode \\
\hline 2000 & The Cell & A sejt & Tarsem Singh \\
\hline 2000 & Xchange & Testesere & Allan Moyle \\
\hline 2001 & Artificial Intelligence: AI & A. I. - Mesterséges értelem & Steven Spielberg \\
\hline 2001 & Avalon & Avalon - Virtuális csapda & Mamoru Oshii \\
\hline 2001 & Swordfish & Kardhal & Dominic Sena \\
\hline 2001 & Vanilla Sky & Vanília égbolt & Cameron Crowe \\
\hline 2002 & Equilibrium & $\begin{array}{l}\text { Equilibrium - Gyilkos nyu- } \\
\text { galom }\end{array}$ & Kurt Wimmer \\
\hline 2002 & Impostor & Imposztor & Gary Fleder \\
\hline 2002 & Minority Report & Különvélemény & $\begin{array}{l}\text { Steven Spielberg } \\
\text { Andy Jones, Peter }\end{array}$ \\
\hline 2003 & Animatrix & Animátrix & $\begin{array}{l}\text { Chung, Takeshi } \\
\text { Koike }\end{array}$ \\
\hline 2003 & Avatar & & Nicolai Amter \\
\hline 2003 & Cube 2: Hypercube & Kocka 2. - Hiperkocka & Andrzej Sekula \\
\hline 2003 & Paycheck & A felejtés bére & John Woo \\
\hline
\end{tabular}




\begin{tabular}{|c|c|c|c|}
\hline Évszám & Eredeti cím & Magyar cím & Rendező \\
\hline 2003 & $\begin{array}{l}\text { Terminator } 3 \text { : Rise of the } \\
\text { Machines }\end{array}$ & $\begin{array}{l}\text { Terminátor 3. - A gépek } \\
\text { lázadása }\end{array}$ & Jonathan Mostow \\
\hline 2003 & The Matrix Reloded & Mátrix - Újratöltve & $\begin{array}{l}\text { Andy Wachowski, } \\
\text { Larry Wachowski }\end{array}$ \\
\hline 2003 & The Matrix Revolution & Mátrix - Forradalmak & $\begin{array}{l}\text { Andy Wachowski, } \\
\text { Larry Wachowski }\end{array}$ \\
\hline 2004 & Avatar & & Jian Hong Kuo \\
\hline 2004 & Cube Zero & Kocka 3. - Cube Zero & Ernic Barbarash \\
\hline 2004 & I, Robot & Én, a robot & Alex Proyas \\
\hline 2004 & $\begin{array}{l}\text { Inosensu: Kokaku kidotai (Ghost } \\
\text { in the Shell 2. - Innocence) }\end{array}$ & $\begin{array}{l}\text { Páncélba zárt szellem 2. - } \\
\text { Ártatlanság }\end{array}$ & Mamoru Oshii \\
\hline 2005 & Sigma & & Jesse Heffring \\
\hline 2006 & A Scanner Darkly & Kamera által homályosan & Richard Linklater \\
\hline 2006 & Paprika & Paprika & Satoshi Kon \\
\hline 2006 & $\begin{array}{l}\text { Saibogujiman kwenchana (I'm a } \\
\text { Cyborg, But That's OK) }\end{array}$ & $\begin{array}{l}\text { Cyborg vagyok, amúgy min- } \\
\text { den oké }\end{array}$ & Chan-wook Park \\
\hline 2007 & Next & Next - A holnap a múlté & Lee Tamahori \\
\hline 2008 & Babylon A.D. & Babylon A.D. & Mathieu Kassovitz \\
\hline 2008 & Radio Frec Albemuth & & John Alan Simon \\
\hline 2008 & Xenobites & & Michacl Fredianelli \\
\hline 2009 & Avatar & & James Cameron \\
\hline 2009 & Screamers 2 & & Sheldon Wilson \\
\hline 2009 & Terminator - Salvation & Terminátor - A megváltás & $\begin{array}{l}\text { Joseph McGinty } \\
\text { Mitchell }\end{array}$ \\
\hline
\end{tabular}

